\title{
PENGEMBANGAN SUMBER DAYA MANUSIA ORGANISASI LEMBAGA PEMBERDAYAAN MASYARAKAT DALAM PEMBERDAYAAN PETANI MISKIN
}

\author{
Kahar $^{1}$, Abdul Mahsyar² ${ }^{2}$ Anwar Parawangi $^{3}$, Fatmawati $^{4}$ \\ 1,2,3,4 Universitas Muhammadiyah Makassar \\ e-mail : kaharsaleh@unismuh.ac.id
}

\begin{abstract}
This research is motivated by the development of Community Empowerment Institution resources which function as a forum for village communities to plan development and foster village communities. The research method aims to describe the development of local government capacity in empowering farming communities in Bulukumba Regency. In this case, this research uses descriptive type to describe the observed behavior. The research focus is based on the grinddle theory which looks at resources, organizational strengthening, and institutional reform. Data collection includes in-depth interviews, observations and documentation. In his research for about 3 months, the data analysis technique in this study was carried out qualitatively. The results of the study indicate that in carrying out its functions, institutional management is not optimal in developing community empowerment of farmers. Flexible and adaptive institutional development in order to optimize the achievement of national development in a synergistic manner between the central government, regional governments, and institutions. and the factors that hinder Community Empowerment Institutions in carrying out their functions are due to the absence of innovation in management so that there are limited collaboration networks or partnerships with other institutions.
\end{abstract}

Keywords: development, empowerment, resources, capacity, institutions.

\begin{abstract}
Abstrak
Penelitian ini dilatarbelakangi mengenai pengembangan sumber daya Lembaga Pemberdayaan Masyarakat yang berfungsi sebagai wadah bagi masyarakat desa merencanakan pembangunan dan pembinaan masyarakat Desa. Metode penelitian bertujuan untuk mendeskripsikan pengembangan kapasitas pemerintah daerah dalam pemberdayaan masyarakat petani di Kabupaten Bulukumba. Dalam hal ini penelitian ini menggunakan tipe deskriptif untuk mendeskripsikan perilaku yang diamati. Fokus penelitian berdasarkan dari teori grinddle yang melihat dari sumberdaya, penguatan organisasi, dan pembaruan institusi. Pengumpulan data meliputi wawancara yang mendalam, pengamatan dan dokumentasi. Dalam penelitiannya sekitar 3 bulan, teknik analisis data dalam penelitian ini dilakukan secara kualitatif. Hasil penelitian menunjukkan bahwa dalam menjalankan fungsinya disebabkan karena manajemen kelembagaan belum optimal dalam pengembangan pemberdayaan masyarakat petani. Pengembangan kelembagaan yang fleksibel dan adaptabel guna optimalisasi capaian pembangunan nasional secara sinergis antara pemerintah pusat, daerah, dan lembaga. dan faktor yang menghambat Lembaga Pemberdayaan Masyarakat dalam menjalankan fungsinya disebabkan karena ketiadaan inovasi dalam pengelolaan sehingga Keterbatasan jaringan kerjasama atau kemitraan dengan lembaga lain.
\end{abstract}

Kata Kunci : pengembangan, pemberdayaan, sumberdaya, kapasitas, lembaga.

\section{PENDAHULUAN}

Pemerintah merupakan pihak yang paling bertanggungjawab dalam mengatasi permasalahan-permasalahan yang dihadapi oleh Negara. Namun demikian, hal tersebut akan dapat diatasi secara efektif dan efisien dengan adanya partisipasi masyarakat. Dengan membentuk suatu wadah organisasi masyarakat yang berpartisipasi membantu pemerintah dalam mengatasi masalah.

UU Nomor 6 tahun 2014 tentang Desa (UU Desa) menyebutkan bahwa desa adalah desa dan desa adat atau yang disebut dengan nama lain, selanjutnya disebut Desa, adalah kesatuan masyarakat hukum yang memiliki 
batas wilayah yang berwenang untuk mengatur dan mengurus urusan pemerintahan, kepentingan masyarakat setempat berdasarkan prakarsa masyarakat, hak asal usul, dan/atau hak tradisional yang diakui dan dihormati dalam sistem pemerintahan Negara Kesatuan Republik Indonesia.

Menurut Peraturan Daerah Kabupaten Bulukumba Nomor 4 tahun 2016 tentang Perlindungan dan Pemberdayaan Petani yang menimbang, (a) bahwa untuk mewujudkan masyarakat yang adil dan makmur serta untuk memenuhi hak dan kebutuhan dasar sebagai warga negara, perlu diselenggarakan upaya perlindungan dan pemberdayaan masyarakat secara terencana, terarah dan berkelanjutan oleh penyelenggara pemerintahan; (b) bahwa adanya kecenderungan meningkatnya perubahan iklim, gejolak ekonomi global, kerawanan terhadap bencana alam dan risiko gagal usaha, serta adanya sistem pasar yang tidak transparan dan tidak berpihak kepada petani, maka diperlukan perlindungan dan pemberdayaan petani.

Sebagaimana dijelaskan oleh Horton et al. (2003) yang menjelaskan bahwa pengembangan kapasitas merupakan "an ongoing process to increase the ability of organization to carry out its functions and acheive its objectives, and to learn and solve problems". Konsep ini menjelaskan pengembangan kapasitas sebagai kemampuan untuk menampilkan fungsi dasar, yakni pencapaian tujuan, pembelajaran dan penyelesaian masalah. Pendapat ini hampir sama dengan yang dikemukakan oleh Milen (2000) yang melihat capacity building sebagai continuing process of strengthening of ability to perform core function, solve problem, define and achieve objective and understand and deal with development need.

Pentingnya kelembagaan petani diakui dalam pembangunan pertanian, baik di negara industri maupun negara sedang berkembang seperti Indonesia. Namun kenyataan memperlihatkan kecenderungan masih lemahnya kelembagaan petani di negara berkembang, serta besarnya hambatan dalam menumbuhkan kelembagaan pada masyarakat petani. Di sisi lain, globalisasi dan liberalisasi ekonomi sebagai implikasi diratifikasi GATT dan WTO merupakan kenyataan berat yang harus dihadapi oleh negara-negara berkembang, seperti Indonesia. Diperlukan penguasaan teknologi pertanian yang memadai dan kemampuan bersaing dari para petani agar mampu bertahan di tengah-tengah persaingan ekonomi dunia.

Kapasitas perlu dikembangkan untuk membangun potensi manfaat dalam peningkatan informasi dan transfer pengetahuan (Badamas, 2005). Sehubungan dengan hal tersebut, maka diperlukanlah suatu metode pendekatan yang integrasi antara pengetahuan dan pengembangan kapasitas yang dikenal dengan manajemen pengetahuan (Knowledge Management / KM). Knowledge management merupakan sistem yang dibuat untuk menciptakan, mendokumentasikan, menggolongkan dan menyebarkan knowledge dalam organisasi sehingga knowledge mudah digunakan kapanpun diperlukan, oleh siapa saja sesuai dengan tingkat otoritas dan kompetensinya termasuk petani kecil, penyuluh, pedagang, industri kecil dan stakeholders lainnya yang terlibat dalam pengembangan dan diseminasi inovasi teknologi. Pentingnya KM dapat memberikan kontribusi yang besar dalam penyelesaian masalah organisasi terutama dalam peningkatan kapasitas organisasi dan individu demi peningkatan inovasi dan keunggulan kompetitif (Menaouer (2015), dalam hal ini knowledge management dapat membantu dalam mengembangkan kapasitas petani dan kelembagaan di kawasan pertanian.

Kenyataan menunjukkan bahwa programprogram pembangunan semakin sulit untuk menjangkau petani kecil secara individu yang jumlahnya sangat banyak. Situasi ekonomi yang ada, infrastruktur, serta kebijakan yang diciptakan oleh pemerintah seringkali mendorong petani-petani dengan lahan sempit dan buruh tani terdesak ke arah marginalisasi secara ekonomi dan sosial. Selain penguasaan atas lahan pertanian yang sempit, nilai tukar pertanian yang rendah, kebijakan pertanian yang tidak berpihak ke petani semakin mendorong terpuruknya petani ke dalam kemiskinan.

Hal tersebut juga terjadi pada Lembaga Pemberdayaan Masyarakatdi Desa Moncongloe kecamatan Ujung Loe Kabupaten Bulukumba, sejak dibentuknya Lembaga Pemberdayaan Masyarakatdi Desa Moncongloe, menunjukkan Kinerja yang banyak mengalami penurunan. Hal ini disebabkan oleh 'kekurangpahaman' 
anggota/pengurus tentang tugas pokok dan fungsi dari Lembaga Pemberdayaan Masyarakat, selain itu juga karena kinerja pengurus/anggota Lembaga Pemberdayaan Masyarakat itu sendiri yang belum optimal, sehingga perlu ditingkatkan kinerja pengurus / anggota agar Lembaga Pemberdayaan Masyarakatbias berkembang kearah yang lebih baik dan bisa membantu masyarakat desa dalam meningkatkan kesejahteraan masyarakat.

Adapun

faktor-faktor

yang

mempengaruhi menururnnya kinerja LPM di Desa Moncongloe, karena SDM LPM yang belum menguasai sistem alih teknologi mengikuti perkembangan yang ada, keberadaan infrastruktur yang tidak sesuai dengan kebutuhan petani, terbatasnya akses layanan usaha terutama di permodalan, dan masih panjangnya mata rantai tata niaga pertanian, sehingga menyebabkan petani tidak dapat menikmati harga yang lebih baik, karena pedagang telah mengambil untung terlalu besar dari hasil penjualan.

\section{KAJIAN LITERATUR}

\section{Tinjauan Pengembangan Organisasi}

Pengembangan adalah suatu usaha untuk meningkatkan kemampuan teknis, teoritis, konseptual, dan moral sesuai dengan kebutuhan melalui pendidikan dan latihan. Pengembangan adalah suatu proses mendesain pembelajaran secara logis, dan sistematis dalam rangka untuk menetapkan segala sesuatu yang akan dilaksanakan dalam proses kegiatan belajar dengan memperhatikan potensi dan kompetensi peserta didik (Majid, 2015:24).

Maka pengembangan pembelajaran lebih realistik, bukan sekedar idealisme pendidikan yang sulit diterapkan dalam kehidupan. Pengembangan pembelajaran adalah usaha meningkatkan kualitas proses pembelajaran, baik secara materi maupun metode dan subtitusinya. Secara materi, artinya dari aspek bahan ajar yang disesuaikan dengan perkembangan pengetahuan, sedangkan secara metodologis dan subtansinya berkaitan dengan pengembangan strategi pembelajaran, baik secara teoritis maupun praktis (Hamdani, 2013:24).

Penelusuran definisi capacity building memiliki variasi antar satu ahli dengan ahli lainnya. Hal ini dikarenakan capacity building merupakan kajian yang multidimensi, dapat dilihat dari berbagai sisi, sehingga pendefinisian yang masih sulit didapat. Secara umum konsep capacity building dapat dimaknai sebagai proses membangun kapasitas individu, kelompok atau organisasi. Capacity building dapat juga diartikan sebagai upaya memperkuat kapasitas individu, kelompok atau organisasi yang dicerminkan melalui pengembangan kemampuan, ketrampilan, potensi dan bakat serta penguasaan kompetensi-kompetensi sehingga individu, kelompok atau organisasi dapat bertahan dan mampu mengatasi tantangan perubahan yang terjadi secara cepat dan tak terduga. Capacity building dapat pula dimaknai sebagai proses kreatif dalam membangun kapasitas yang belum nampak.

\section{a. Definisi Kapasitas}

Menurut Milen menyatakan kapasitas adalah kemampuan individu, organisasi atau sistem untuk menjalankan fungsi sebagai mestinya secara efektif, efisien dan terus menerus. Sedangkan Morgan merumuskan pengertian Kapasitas adalah sebagai kemampuan, keterampilan, sikap, nilai-nilai, hubungan, perilaku, dan motivasi sumber daya dan kondisi-kondisi yang memungkinan setiap individu, organisa, atau jaringan sector dan system yang lebih luas untuk melaksanakan fungsi-fungsi mereka dalam mencapai tujuan pembangunan yang telah ditetapkan dari waktu ke waktu.

Milen melihat Capaciti building sebagai tugas khusus, karena tugas khusus tersebut berhubungan dalam sector-sektor organisasi atau system tertentu pada sewaktu waktu tertentu. Sesungguhnya pada literature pembangunan, konsep capacity building sampai saat ini masih mengisahkan perdebatan-perdebatan dalam pendefinisian. Sebagai pakar memaknai capacity building sebagai capacity development atau capacity straitening, mengisyaratkan suatu prakarsa pada pengembangan kemampuan merujuk kepada construction capacity sebagai proses kreatif membangun kapasitas yang belum Nampak. Namun, Soeprato tidak cenderung pada salah satu titik karena menurutnya kedua sector memiliki karakteristik diskusi yang sama yakni analisa kapasitas sebagai inisiatif lain untuk meningkatkan kinerja pemerintahan 
(goverment performace). Dalam pengembangan kapasistas memiliki dimensi, fokus dan tipe kegiatan, dimensi, fokus dan tipe kegiatan menurut Greenlee yaitu dimensi pengembangan SDM dengan fokus personil yang professional dan kemampuan teknis serta tipe kegiatan seperti: trainning, praktek langsung, kondisi iklim kerja, dan rekrutmen.

Sejalan dengan itu Greenlee menyatakan bahwa apabila capacity building menjadi serangkaian strategi yang ditunjuk untuk meningkatkan efisiensi efektivitas dan responsivitas, maka capaciti building tersebut harus memusatkan perhatian kepada dimensi. Pengembangan sumber daya manusia, penguatan organisasi dan reformasi kelembagaan dalam konteks pengembangan sumber daya manusia perhatian diberikan kepada pengadaan atau penyediaan personil yang professional dan teknis. Kegiatan yang dilakukan antara lain pendidikan dan latihan (training), pemberian gaji atau upah pengaturan kondisi dan lingkungan kerja dan system rekrutmen yang tepat. Dalam kaitannya dengan penguatan organisasi pusat perhatian ditujukan kepada manajemen untuk memperbaiki kinerja fungsi-fungsi dan tugastugas yang ada dan pengaturan struktur mikro.

\section{b. Kapasitas Building}

Pengembangan kapasitas (capacity development) adalah sebuah pendekatan yang pada masa sekarang ini secara luas digunakan dalam pembangunan masyarakat (community development). Istilah pengembangan kapasitas telah digunakan sejak tahun 1990an oleh negara-negara donor untuk memperbaiki kapasitas negara partner (negara yang mendapat bantuan). Untuk memahami konsep pengembangan kapasitas kita terlebih dahulu perlu memahami pengertian kapasitas.

Kebanyakan literatur mendefinisikan kapasitas sebagai kemampuan umum untuk melaksanakan sesuatu. UNDP mendefinisikan kapasitas sebagai kemampuan memecahkan masalah yang dimiliki seseorang, organisasi, lembaga, dan masyarakat untuk secara perorangan atau secara kolektif melaksanakan fungsi, memecahkan masalah, serta menetapkan dan mencapai tujuan (UNDP, 2016).

Sedangkan menurut Soeprapto (2012:11) tentang pengertian Pengembangan Kapasitas, yaitu:
1) Pengembangan kapasitas bukanlah produk, melainkan sebuah proses.

2) Pengembangan kapasitas adalah proses pembelajaran multi-tingkatan meliputi individu, grup, organisasi, dan system.

3) Pengembangan kapasitas menghubungkan ide terhadap sikap.

4) Pengembangan kapasitas dapat disebut sebagai actionable learning dimana pengembangan kapasitas meliputi sejumlah proses-proses pembelajaran yang saling berkaitan, akumulasi benturan yang menambah prospek untuk individu dan organisasi agar secara terusmenerus beradaptasi atas perubahan.

Definisi lain menyatakan bahwa capacity building adalah upaya untuk meningkatkan kemampuan rakyat Negara sedang berkembang untuk mengembangkan keterampilan manajemen dan kebijakan yang esensial yang dibutuhkan untuk membangun struktur budaya, sosial politik, ekonomi dan SDM.

Sementara itu capacity building didefinisikan oleh Brown (2013:25) sebagai suatu proses yang dapat meningkatkan kemampuan seseorang, suatu organisasi atau suatu sistem untuk mencapai tujuan-tujuan yang telah ditetapkan. Pengertian lain mengenai capacity building menyatakan bahwa capacity building umumnya dipahami sebagai upaya membantu pemerintah, masyarakat ataupun individu dalam mengembangkan keahlian dan keterampilan yang dibutuhkan untuk mewujudkan tujuantujuan mereka. Program pengembangan kapasitas seringkali didesain untuk memperkuat kemampuan dalam mengevaluasi pilihan-pilihan kebijakan mereka dan menjalankan keputusan-keputusan yang dibuat secara effektif.

\section{METODE}

Penelitian ini menggunakan pendekatan penelitian kualitatif dengan menyajikan temuan dan hasil analisis dengan menggunakan desain studi kasus.

\section{HASIL DAN PEMBAHASAN}

Upaya yang dilakukan Lembaga Pemberdayaan Masyarakat untuk memajukan 
petani di Kecamatan Ujungloe, yaitu memberikan sosialisasi dan pelatihan dalam pengembangan teknik menanam secara berkelanjutan, yaitu satu bulan sekali dalam melaksanakan pemberdayaan kepada petani terkait pengembangan aspek sistem bertani yang dapat digunakan dengan teknik tanam agar lebih menghemat energi namun memberikan hasil maksimal dan memberikan pengetahuan lanjutan.

Pemberdayaan yang dilakukan dalam mengembangkan sumber daya manusia dilakukan melalui tahap sosialisasi dan pelatihan. Kegiatan sosialisasi seperti pengenalan penggunaan pupuk cair ini dilakukan untuk memberikan pengetahuan kepada para petani terkait kegiatan pada pengembangan aspek sistem bertani. Sedangkan pada kegiatan pelatihan dimaksudkan memberikan keterampilan mengenai pola tanam dan teknik menanam agar petani mampu meningkatkan produksi hasil panen.

Berdasarkan hasil observasi dilapangan menunjukkan partisipasi petani mengikuti kegiatan sosialisasi yang diadakan pengembangan aspek sistem bertani. melalui kegiatan tersebut petani mendapatkan berbagai pengetahuan terkait dengan penanaman.

Dengan dilaksanakannya kegiatan pengembangan aspek sistem bertani dapat menunjang dan mengembangkan usaha petani melalui sosialisasi dan pelatihan dalam pengembangan aspek sistem bertani. Adanya pelaksanaan sosialisasi terkait program untuk pengembangan aspek sistem bertani dirasakan sangat membantu para petani. Dengan kegiatan sosialisasi kepada petani, mereka menjadi tahu apa saja yang akan di peroleh petani dan dampak positif ketika mengikuti pengembangan aspek sistem bertani.

Berdasarkan hasil observasi dilapangan menunjukkan bahwa kegiatan sosialisasi membantu petani meningkatkan pengetahuan bercocok tanam petani. Pada awalnya penggunaan pengembangan aspek sistem bertani yang salah satunya yaitu pengunaan pupuk cair yang sangat meminimkan biaya banyak namun memberikan hasil maksimal. Sehingga sejak adanya kegiatan sosialisasi dan pelatihan petani menjadi tahu tata cara penggunaan pupuk cair tersebut dirasakan efektif. Sehingga hasil produksi panen meningkat dengan biaya yang tidak terlalu tinggi.

Berdasarkan hasil penelitian menunjukkan bahwa kegiatan sosialisasi dilakukan secara bertahap disambut antusias oleh petani. Dimana setiap perwakilan kelompok datang dan mengikuti, selanjutnya perwakilan kelompok yang menyampaikan kepada anggota kelompok lainnya terkait materi sosialisasi.

Selain dilakukan pemberdayaan pengembangan usahatani kelompok tani, pemerintah juga mengadakan penyuluhan yang diikuti oleh berbagai kelompok tani yang tergabung dalam program pengembangan aspek sistem. Adapun dalam pelaksanaan kegiatan, kelompok tani menghadapi berbagai kendala.

Berdasarkan hasil observasi dilapangan menunjukkan kendala yang ditemu dilapangan cukup banyak, mulai dari pemenuhan kebutuhan Pupuk cair, ketersediaan tenaga mengolah, dan tentunya hama tanaman yang cukup banyak.

Dalam pelaksanaan program pengembangan sumber daya melalui pengembangan aspek sistem terdapat kendalakendala yang menyebabkan masyarakat tidak dapat mengembangkan program tersebut. Hampir semua penyuluh pendamping yang ada di Kecamatan Ujungloe memiliki masalah yang sama, sehingga program tersebut tidak berjalan sesuai dengan yang diharapkan. Dari kendala-kendala yang ada diantaranya adalah pertama, hampir semua pengurus Lembaga Pemberdayaan Masyarakat rata-rata bermata pencaharian sebagai petani. Kedua, karena kesibukan masing-masing anggota, walaupun tingkat pendidikannya memadai, tetapi karena tanggung jawabnya kepada keluarga lebih penting jadi program pengembangan aspek sistem menjadi terabaikan. Dan yang ketiga, hampir semua pengurus yang ada di Lembaga Pemberdayaan Masyarakat kurang begitu menguasai tentang pembukuan laporan keuangan. Selain itu adanya anggapan masyarakat mengenai bantuan dana hibah yang harus dibagi rata dan tidak perlu dikembangkan untuk program Lembaga Pemberdayaan Masyarakat.

Pelaksanaan pemberdayaan petani, Lembaga Pemberdayaan Masyarakat selama pelaksanaan banyak menemui kendala. Mulai dari kelompok tani yang tergabung dalam 
petani Lembaga Pemberdayaan Masyarakat sebagai anggota sekaligus sebagai pengelola pemberdayaan petani Lembaga Pemberdayaan Masyarakat, juga datang dari pihak pengawas program pemberdayaan petani Lembaga Pemberdayaan Masyarakat. Namun dibalik kendala yang dihadapi petani, pihak pemerintah juga tetap berusaha mengupayakan memberikan solusi kepada masyarakat.

Upaya-upaya yang dilakukan agar masyarakat dapat mengembangkan program pengembangan usaha Lembaga Pemberdayaan Masyarakat melalui pengembangan aspek sistem dari pihak penyuluh pendamping sendiri hanya bisa memberikan saran-saran atau masukan yang nantinya dapat memotivasi masyarakat agar tergerak hati dan pikirannya dan mau sekaligus mampu dalam mengembangkan program yang direncanakan oleh Lembaga Pemberdayaan Masyarakat. Selain itu dari pihak penyuluh juga melakukan pendekatan secara perlahan-lahan kepada masyarakat.

Dengan adanya program pengembangan aspek sistem yang dicanangkan oleh Lembaga Pemberdayaan Masyarakat ini diharapkan semua anggota kelompok tani yang ada di Kecamatan Ujungloe mampu berubah menjadi kelompok tani yang mandiri. Dimana dengan adanya penyuluhan dan program dari Lembaga Pemberdayaan Masyarakat ini dapat memenuhi semua kebutuhan yang diperlukan oleh petani mulai dari produksi, pengolahan hasil produksi hingga pemasaran hasil tanaman khususnya dibidang pertanian.

Dari obervasi yang dilakukan, peneliti mengamati bahwa dari pihak penyuluh juga mengadakan sosialisasi sekaligus pelatihan kepada masyarakat khususnya petani di Kecamatan Ujungloe mengenai bagaimana cara memproduksi tanaman yang bagus sehingga mampu memperoleh hasil yang lebih menguntungkan dibandingkan sebelumnya.

Hal ini sejalan dengan teori yang dikemukakan oleh Soeprapto (2012:11) yang mengemukakan bahwa pengembangan kapasitas melalui pengembangan SDM dapat disebut sebagai actionable learning dimana pengembangan kapasitas meliputi sejumlah proses-proses pembelajaran yang saling berkaitan, akumulasi pembentukan yang menambah prospek untuk individu dan organisasi agar secara terus menerus beradaptasi atas perubahan.
Kelompok tani sebagai lahan kerjasama, hendaknya memiliki kemampuan untuk melaksanakan kerjasama penyediaan sarana dan jasa dan pertanian (Peraturan Menteri Pertanian 2013). Produksi komoditas pertanian dipengaruhi oleh lahan, air, saran produksi, dan teknologi manajamen yang sekaligus menjadi sarat utama (Suprianti et.al 2014). Kelompok tani dapat menjalankan tugas dan kewajibannya antara lain mengkoordinasikan gotong royong untuk pengolahan lahan angota kelompok tani secara bergantian (Mardikanto, 2013). Pengelohan lahan dilakukan secara membolak balik tanah pada lahan menggunakan cangkul atau traktor. Cara ini akan membantu menggemburkan tanah sehingga akan mempermudah perakaran masuk kedalam tanah (Hariadi, 2015).

Berdasarkan pada proses yang dilakukan kelompok tani dengan mengikuti sosialisasi dan berbagai pelatihan serta pendampingan yang dilakukan menunjukkan sebuah proses untuk pengembangan kapasitas. Melali tahapan belajar (pelatihan) dan pengawasan dalam praktiknya kelompok tani memiliki keterampilan dalam menanam seperti teknik tanam baru dan pola tanam yang tepat.

\section{KESIMPULAN}

Kesimpulan dalam riset ini adalah pengembangan kapasitas kelompok tani yang dilakukan oleh Lembaga Pemberdayaan Masyarakat melalui beberapa langkah yaitu kelembagaan. Pengembangan kelembagaan yang fleksibel dan adaptabel guna optimalisasi capaian pembangunan nasional secara sinergis antara pemerintah pusat, daerah, dan lembaga. Adapun pengembangan kapasitas kelompok tani yang dilakukan oleh Lembaga Pemberdayaan Masyarakat melalui beberapa langkah yaitu a) struktur kelompok, b) pembinaan dan pengembangan kelompok, c) kekompakan kelompok tani, dan d) kefektifan kelompok tani.

Faktor yang menghambat Lembaga Pemberdayaan Masyarakat Desa dalam menjalankan fungsinya disebabkan karena ketiadaan inovasi dalam pengelolaan sehingga Keterbatasan jaringan kerjasama atau kemitraan dengan lembaga lain. 


\section{REFERENSI}

Achmad Sani Supriyanti dan Vivin Maharani. 2013. Metodologi Penelitian Manajemen Sumber Daya Manusia. Malang: UIN-MalikiPress

Atmo, Soeprapto, Krisdarto. 2012. Мепијu SDM Berdaya. Jakarta: Alex Media Kompatindo.

Brown, Carol V., De Hayes, et al. 2013. Research Methods for Business. Jakarta: PT. Salemba Empat.

Bambang, Hariadi. (2005). Strategi Manajemen. Jakarta: Bayumedia Publishing.

Peraturan Daerah Kabupaten Bulukumba Nomor 4 tahun 2016 tentang Perlindungan dan Pemberdayaan Petani. Lembaga Negara RI Tahun 2016. Bulukumba.

Undang - Undang No. 6 Tahun 2014 tentang Pemerintahan Desa

Mardikanto, Totok dan Poerwoko Soebianto. 2013. Pemberdayaan Masyarakat dalam Perspektif Kebijakan. Bandung: Alfabeta Bandung.

UNDP. (2016). Mercury Management for Sustainable Development. New York: UNDP.

Hamid, Hamdani. 2013. Pengembangan sistem pendidikan di Indonesia, Bandung: pustaka setia.

Abdul Majid, \& Chaerul Rochman. 2015. Pendekatan Ilmiah dalam Implementasi Kurikulum 2013. Bandung: PT. Remaja Rosdakarya.

Menaouer, BS. 2015, Towards a New Approach of Support Innovation Guided by Knowledge Management: Application on FERTIAL.Procedia Social and Behavioral Sciences: 260269.

Badamas, M.A. (2005). Information Technology for Sustainable Development and Global Competitiveness: Comparing Curriculum in Africa and America. World Review of Science, Technology and Sustainable Development, 261-276.

Horton, William \& Horton, Katherine. (2003). E-Learning Tools and Technologies: A consumer guide for trainers, teachers, educators, and instructional designers. USA : Wiley Publishing, Inc. 